Article

\title{
Accessibility of Vaccination Centers in COVID-19 Outbreak Control: A GIS-Based Multi-Criteria Decision Making Approach
}

\author{
Kadir Diler Alemdar ${ }^{1}$, Ömer Kaya ${ }^{1}\left(\mathbb{D}\right.$, Muhammed Yasin Çodur ${ }^{1}$, Tiziana Campisi ${ }^{2, *(D)}$ and \\ Giovanni Tesoriere ${ }^{2}$ (D) \\ 1 Civil Engineering Department, Engineering and Architecture Faculty, Erzurum Technical University, \\ Erzurum 25050, Turkey; kadir.alemdar@erzurum.edu.tr (K.D.A.); omer.kaya@erzurum.edu.tr (Ö.K.); \\ mycodur@erzurum.edu.tr (M.Y.Ç.) \\ 2 Faculty of Engineering and Architecture, Kore University of Enna, 94100 Enna, Italy; \\ giovanni.tesoriere@unikore.it \\ * Correspondence: tiziana.campisi@unikore.it
}

Citation: Alemdar, K.D.; Kaya, Ö.; Çodur, M.Y.; Campisi, T.; Tesoriere, G. Accessibility of Vaccination Centers in COVID-19 Outbreak Control: A GIS-Based Multi-Criteria Decision Making Approach. ISPRS Int. J. Geo-Inf. 2021, 10, 708. https:// doi.org/10.3390/ijgi10100708

Academic Editors: Giuseppe Borruso, Ginevra Balletto, Beniamino Murgante, Carmelo Maria Torre, Hartmut Asche and Wolfgang Kainz

Received: 22 September 2021

Accepted: 11 October 2021

Published: 16 October 2021

Publisher's Note: MDPI stays neutral with regard to jurisdictional claims in published maps and institutional affiliations.

Copyright: (c) 2021 by the authors. Licensee MDPI, Basel, Switzerland. This article is an open access article distributed under the terms and conditions of the Creative Commons Attribution (CC BY) license (https:// creativecommons.org/licenses/by/ $4.0 /)$.
Abstract: The most important protective measure in the pandemic process is a vaccine. The logistics and administration of the vaccine are as important as its production. The increasing diffusion of electronic devices containing geo-referenced information generates a large production of spatial data that are essential for risk management and impact mitigation, especially in the case of disasters and pandemics. Given that vaccines will be administered to the majority of people, it is inevitable to establish vaccination centres outside hospitals. Site selection of vaccination centres is a major challenge for the health sector in metropolitan cities due to the dense population and high number of daily cases. A poor site selection process can cause many problems for the health sector, workforce, health workers, and patients. To overcome this, a three-step solution approach is proposed: (i) determining eight criteria using from the experience of the advisory committee, (ii) calculating criterion weights using Analytic Hierarchy Process (AHP), and performing spatial analysis of criteria using Geographic Information System (GIS), (iii) assigning potential vaccination centres by obtaining a suitability map and determining service areas. A case study is performed for Bağcllar, Istanbul district, using the proposed methodology. The results show that the suitable areas are grouped in three different areas of the district. The proposed methodology provides an opportunity to execute a scientific and strategic vaccination programme and to create a map of suitable vaccination centres for the countries.

Keywords: COVID-19; vaccination; outbreak management; site selection; Turkey

\section{Introduction}

The struggle of human beings against the COVID-19 outbreak has been continuing for more than a year. The spread of this pandemic was tried to be prevented by many measures such as lockdown, online education, quarantine, travel restrictions, etc. [1-8]. This situation has affected people's lifestyle in all aspects in terms of habits of social, economic, transportation, and health [9-11]. The most important method of struggle that will completely or partially eliminate the existence of the virus is a vaccine, as in the past [12]. COVID-19 vaccine will play a vital role in saving people's lives [13]. Vaccines developed against pandemics are shown as a way out of the pandemic. COVID-19 vaccine studies are carried out by many governments/manufacturers with various methods [14]. The logistics and administration of the vaccine are as significant as the production of the vaccine in fighting the pandemic. The importance of allocating suitable areas for vaccine administration is increasing day by day.

"Nobody is safe until everyone is safe". Vaccination of all humanity is a big challenge. Prevention of the pandemic is possible not only in vaccination of certain countries but also 
in all countries. The most important step after the distribution of vaccines to countries is the rapid and health administration of the vaccine to the target group. Since COVID-19 is a very dangerous and fast-spreading virus, policymakers and other stakeholders can not only focus on vaccination centres' capacities and health workers' capabilities when they are planning to establish vaccination centres. Furthermore, they must take into account the location of vaccination centres. Due to both the structure of the vaccine and the pandemic conditions, the determination as positional of vaccination centres before vaccine distribution requires a scientific and strategic infrastructure. Determining the most suitable locations of vaccination centres is expressed as a site selection problem. Site selection for a vaccination centre is not only affected by only one factor or medical-related factors [9].

Since more than one criterion should be considered in the solution of vaccination centres' site selection studies, these studies are a multi-criteria decision-making problem and multi-criteria decision analysis (MCDA techniques) are generally used for these studies. In addition, GIS techniques are generally preferred in the literature for the spatial analysis needed for the solution of site selection problems. In the literature, both spatial analysis and MCDA techniques are used together or separately in the solution of the site selection problem.

In this paper, scientific and strategic decision-making and geographical analysis methodology are carried out to determine new locations of vaccination centres. The locations of centres were studied as a solution/prevention to the dissemination and huge impact on the social, economic, health of COVID-19. To do so, a three-step approach is developed and applied. Firstly, eight criteria affecting optimal siting of vaccination centres were considered and the data of criteria were gathered. Secondly, the weighting process was performed via Analytic Hierarchy Process (AHP). Then, data of criteria was transferred to GIS and spatial analyses of each criterion were conducted via GIS. The overlapping process was applied to the criteria layer using criteria weights obtained from AHP. In the last section, a suitability map for vaccination centre locations was obtained and new vaccination centres wereassigned according to suitable areas.

The paper is organised as follows: the second section provides brief information about literature studies on-site selection problem, COVID-19 vaccines, and vaccination centres and the contribution of this study to the topic, while the third section presents the study area and criteria definition information. In the next section, information about the proposed methodology to solve the site selection problem vaccination centres give. In the fifth and sixth sections, there are results of the GIS-based MCDA approach, the sensitivity analysis, and a discussion of the paper. Finally, the last section summarises the main conclusions of this study.

\section{Literature Review}

Site selection is always an important topic for city planning, decision-making, and geographical analysis science. Thus, a lot of research about the on-site selection problem has been done in the last two decades [15-19]. Researchers have used various analytic and analysis methods such as mathematical models, artificial intelligence, imagine processing, machine learning methods, geographical programmes, and verbal definitions. In recent years, MCDA methods and GIS have become increasingly popular as a technique for various fields of site selection studies [20-24]. The integration of MCDA and GIS techniques has been proven with the literature studies, and it is an important spatial decision support system for analyzing suitable locations. Using the integration has been addressed to tackle and analyse challenges in site selection problems. These studies are disaster monitoring and prevention [25-27], public safety [28,29], wind and solar farms [30,31], pedestrian crossing [32,33], park and ride area [34], sustainable shelter [35], hospital siting [36], electric vehicle infrastructure [37]. Thus, in our literature review section, we focus on the site selection studies in the field of health and various. The previous studies on site selection, COVID-19 vaccines, and vaccination centres are given in below and Table 1. 
Kutlu Gündoğdu et al. (2018) analysed the service quality dimension for organ transplantation at three popular hospitals in Istanbul. Four main (Tangibles, Reliability, Responsiveness, Empathy) and 12 sub-criteria were determined for the locations of alternative hospitals, and hesitant fuzzy Evaluation Based on Distance from Average Solution (EDAS) was used for evaluation. In addition, some slight changes were observed by comparing the results with the hesitant fuzzy Technique for Order of Preference by Similarity to Ideal Solution (TOPSIS) [38].

Zolfani et al. (2020) drew attention to the pressure and risk on the health system and workers during the COVID-19 pandemic. The establishment of new temporary hospitals to struggle against pandemics was evaluated with MCDA methods. Performance scores of these hospitals, which are planned to be established in a total of five different districts in Istanbul, were analysed. For this analysis, three main (technological, economic, and social) and nine sub-criteria were taken into consideration [9].

Li \& Li (2021) comprehensively examined the currently developed vaccines against the COVID-19 virus. Animal experiments and clinical research results of the vaccines were presented comparatively. Readers, detailed information about vaccines can be found in this study [14].

Table 1. Application of various techniques in solution of site selection problems.

\begin{tabular}{ccc}
\hline Study Topics of the Site Selection & Methodologies & References \\
\hline Hospital & TOPSIS-ANP, Hesitant Fuzzy TOPSIS & {$[36,39]$} \\
Hospital for organ transplantation & Hesitant Fuzzy EDAS & {$[38]$} \\
Renewable energy systems & A fuzzy set theory and GIS & {$[40]$} \\
Organic farming & AHP and GIS & {$[41]$} \\
Electric vehicle charging station & GIS-AHP-TOPSIS, & {$[37,42-44]$} \\
Car sharing & GIS-AHP-PROMETHEE-VIKOR, & {$[45,46]$} \\
Logistic centers & Entropy-ELECTRE, Genetic Algorithm & {$[9,47]$} \\
Wind and Solar Farm & MULTIMOORA, WASPAS-TOPSIS & {$[30,31,48]$} \\
Bike sharing stations & AHP-ANP-TOPSIS-GIS, & {$[48]$} \\
Pedestrian Crossing & DEA-R_FUCON-R_CoCoSo & {$[32]$} \\
\hline
\end{tabular}

As it is seen from the given literature, there is no study in the literature about site selection of vaccination centres, studies on this field are lacking. Whereas, it is expressed as "Vaccination is central to controlling COVID-19" [49].

To this end, it is aimed to fill this gap/lack in the literature with this paper. To the best of our knowledge, the GIS-based MCDA approach is the first to use it in the analysis of the vaccination centre locations. The paper contributes to the literature, and these are as follows.

- The solution to the vaccination centre site selection problem was discussed for the first time in this study. For the first time, a GIS-based MCDA approach was proposed for the solution. The accuracy, reliability, and consistency of this approach are proven by studies in the literature.

- For the first time, spatial analysis techniques were used in the field selection of vaccination centres, and suitability analysis was performed for vaccine accessibility. Suitability analysis ensures that all processes from the logistics of the vaccine to the administration of the vaccine were carried out effectively.

- Since vaccination centre site selection is a multi-criteria decision-making problem, the MCDA method was used in this study. To this end, a scientific framework with eight criteria was presented. For the first time, the locations of vaccination centres were determined by considering more than one criterion. There is no study in this field. 
- The assignment of potential vaccination centres was made as three centres according to the suitability map. Service area analysis was carried out with Thiessen Polygon [23] in terms of the accessibility of assigned vaccination centres. The determination of service areas was included in this study for the first time in the literature, and the target group was directed to vaccination centres.

- Istanbul is most affected by the pandemic in Turkey, and this study was conducted in one of the districts of Istanbul with the highest population and number of daily cases. This district, where the risk on the health system is at a high level, was selected as the study area. In addition, this study, which is carried out under the worst-case scenario (high health system risk) conditions, can be easily applied in other study areas. Thanks to this situation, this study becomes a guide for the planned vaccination centres.

- $\quad$ The assigned vaccination centres can also be used as a testing centre for COVID-19 and possible outbreaks in the future, if needed.

- Especially, the location of vaccination centres is very important for the logistic and application of the vaccine in terms of authorised institutions and personnel, health workers, and target groups. The locations of vaccination centres were evaluated with a scientific framework and a guide is presented.

Impacts of COVID-19 on Mobility and Logistics

The recent pandemic has also caused damage to the transport and logistics sector.

On the transport side, there has been a general collapse in the use of public transport and shared mobility due to users' fear and anxiety that they might contract the virus more easily.

At the same time, there has been a total restriction of travel in several countries around the world, followed by a resumption of mostly short-distance travel by foot or bicycle [50]. This is not only related to possible contagion but also to the different habits of users, such as teleworking or the management of family activities (reduction of home-school or home-work trips) [51-53].

In the logistics sector, there has been an increase in the demand of users who have used e-commerce for purchases as well as home delivery of shopping or certain goods such as books or medicines.

In order to curb the resurgence in the use of private vehicles, local authorities, together with national governments, have developed a series of strategies to encourage sustainable mobility.

Since December 2020, the discovery of the vaccine and its spread around the world has resulted in millions of people having to travel to hospitals for administration. Most facilities were not ready to cope, so other facilities were built or reused as vaccine hubs.

Given the complexity of the logistics and the increase in the availability of vaccines over the months, and the implementation of large-scale vaccination campaigns (which involve a more geographically articulated structural model and which envisages the use of a number of vaccination centres), it is important to take into account the fact that the number of vaccines is increasing.

Due to the complex logistics and the increasing availability of vaccines over the months, many cities have highlighted the need to provide for the involvement of existing vaccination centres in the territory and the new facilities of mobile units and military health.

In addition, the need to carry out large-scale vaccination campaigns emerged in some contexts (due to the high number of infected or immunocompromised people or people with pathologies) that required a more articulated organisation model.

In many countries, the need has been highlighted to set up a COVID-19 Vaccination Steering Committee, which would coordinate the vaccination campaign at an institutional level and monitor its progress, as well as a COVID-19 Vaccination Executive Committee to implement the decisions taken. 
Two models have been developed for the administration of vaccines and the choice of vaccination sites, as described below in Figure 1.

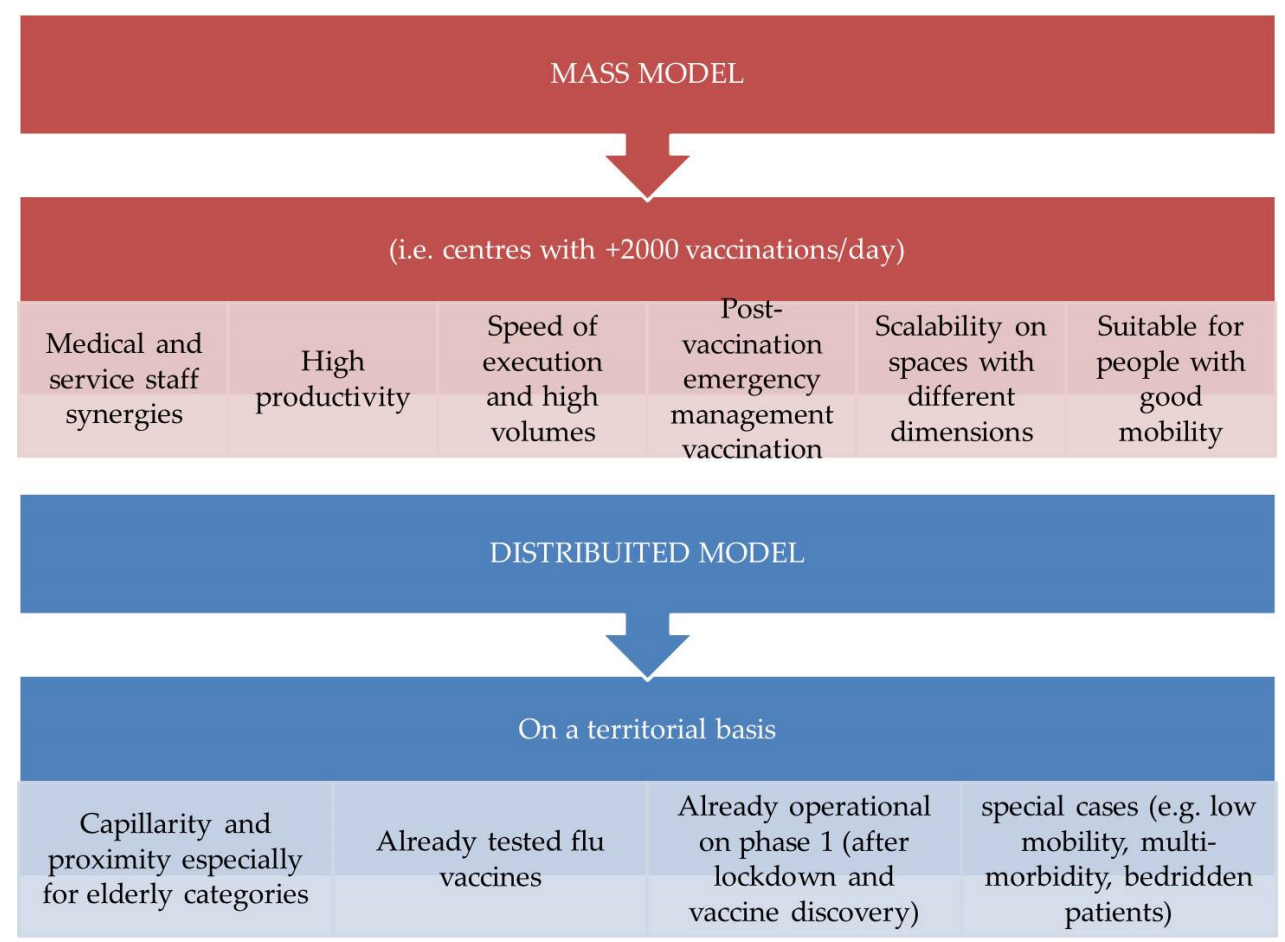

Figure 1. The main models related to vaccines centres spreads in the world.

The following parameters should be considered when defining the vaccination hub areas

- Square metres

- Medical staff

- Health workers

- Administrative staff

- Number of vaccines/day administered

- Productivity (Vaccines/worker/day)

For the geolocation analysis of the above hubs, GIS technology allows for the identification and control of the best areas.

\section{Materials}

In recent years, site selection problems have been frequently encountered in the real-life. There are different approaches in the literature for the solution of site selection problems $[15,16,18,54]$. It also requires a multi-criteria approach for site selection solutions. In this study, it is planned to determine the most suitable locations of the vaccination centres with a scientific strategy. The locations of these centres in metropolitan cities of developed countries were determined superficially. Even this situation has enabled them to reach a very good stage in the vaccination programme [55].

In this study, site selection analysis of vaccination centres was conducted with a scientific perspective in order to carry out the vaccination programme in a healthier, faster, and more reliable way. To do so, in the site selection analysis process, eight criteria were considered in terms of transportation, health, demographic, settlement, and security. While determining these criteria, the author's and expert's opinions were used. The weighting process of evaluation criteria was carried out via AHP. Spatial analysis, which is a key part in determining the location of vaccination centres, was carried out via ArcMap 10.6 
software. As a result of this process, the most suitable areas for vaccination centres were scientifically determined. The flowchart of the study is given in Figure 2.

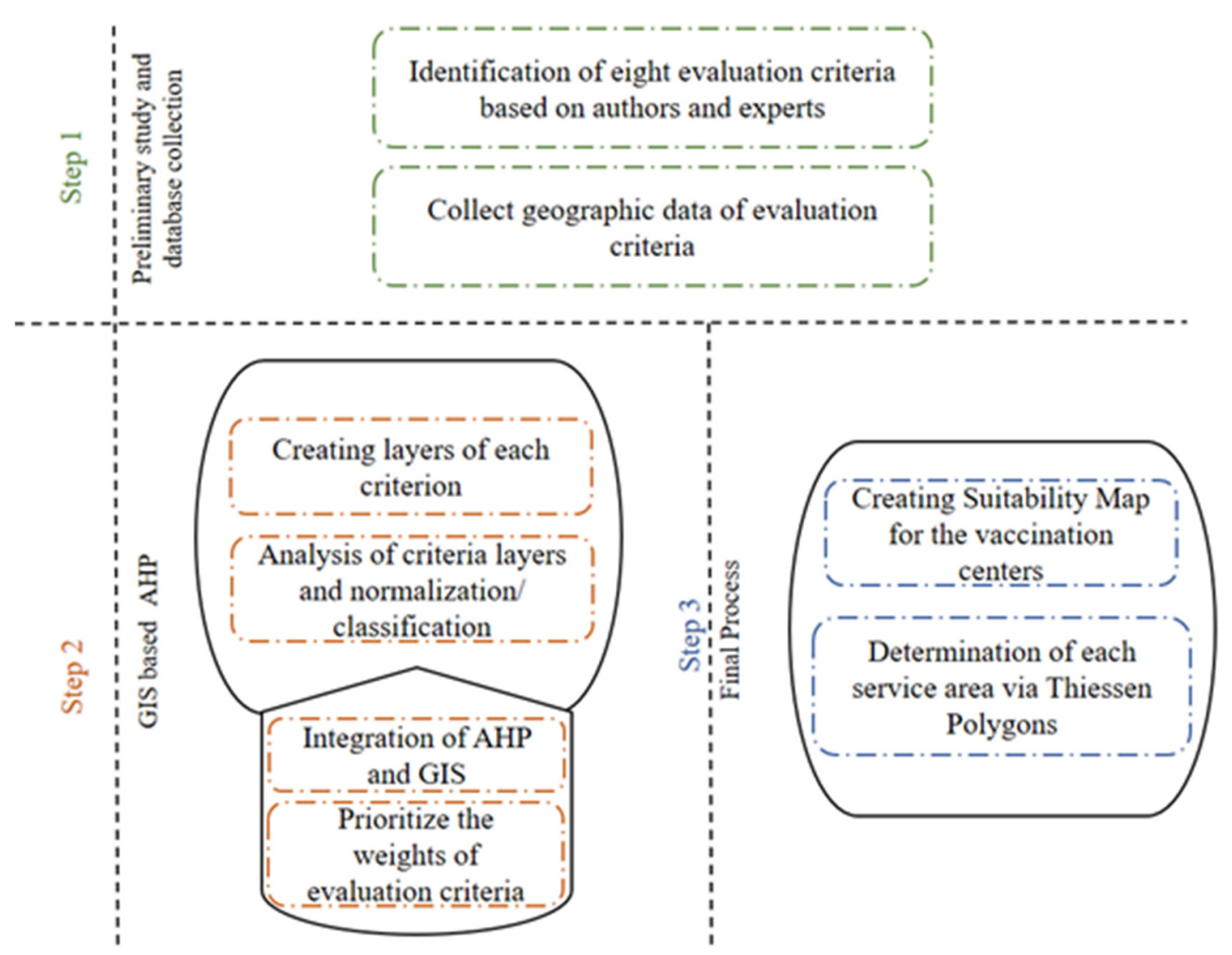

Figure 2. Flowchart of the study.

\subsection{Study Area}

Istanbul can be expressed as a city which is the most affected by the pandemic in terms of economic, social, and health in Turkey [54]. In this way, the mobility of people and vehicles in Istanbul, a metropolitan city, is above the acceptable level [56]. Due to the density of the population, the province where COVID-19 cases are most common is Istanbul in Turkey [57]. Istanbul plays an important role in preventing and treating infections in the COVID-19 pandemic. Therefore, Istanbul should be evaluated as detailed in terms of both case-control and vaccination programmes. Istanbul is divided into European and Anatolian sides where the population is not the same on both sides. The population of the European side is about twice that of the Anatolian side, approximately 5.5 million $[9,58]$.

COVID-19 infections are increasing in Turkey, with 25,817 new infections reported on average each day. That's $43 \%$ of the peak-the highest daily average reported on April 2020. As of 20 September 2021, approximately 5.5 million cases and 50 thousand deaths occurred in Turkey due to the COVID-19 pandemic. Turkey has administered at least 105.611,261 doses of COVID vaccines so far. Assuming every person needs 2 doses, that's enough to have vaccinated about $68.13 \%$ of the country's population [59].

Turkey's most popular vaccine is BioNTech and Sinovac.

Phase 1 (after December 2020 with the 1st dose to the medical group) trials of Turkey's 'most innovative' COVID-19 vaccine candidate were successfully completed in May 2021, and phase 2 studies of the virus-like particle (VLP) vaccine developed by scientists in Turkey's COVID-19 platform have begun.

Turkey has multiple vaccine candidates in development, including seven under the COVID-19 platform. An inactivated coronavirus vaccine developed by Turkish scientists 
was included in a list of vaccines recognised by the World Health Organisation earlier this month.

Bağcllar was selected as the study area in this study because it is one of the most populous $(737,206)$ districts of Istanbul and is the district with the highest number of daily cases according to the data of the Ministry of Health [60-62]. Performing the site selection analysis for vaccination centres in Bağcular, one of the districts that reflects Istanbul, is a guided study for both Istanbul and Turkey. The study area is presented in Figure 3.

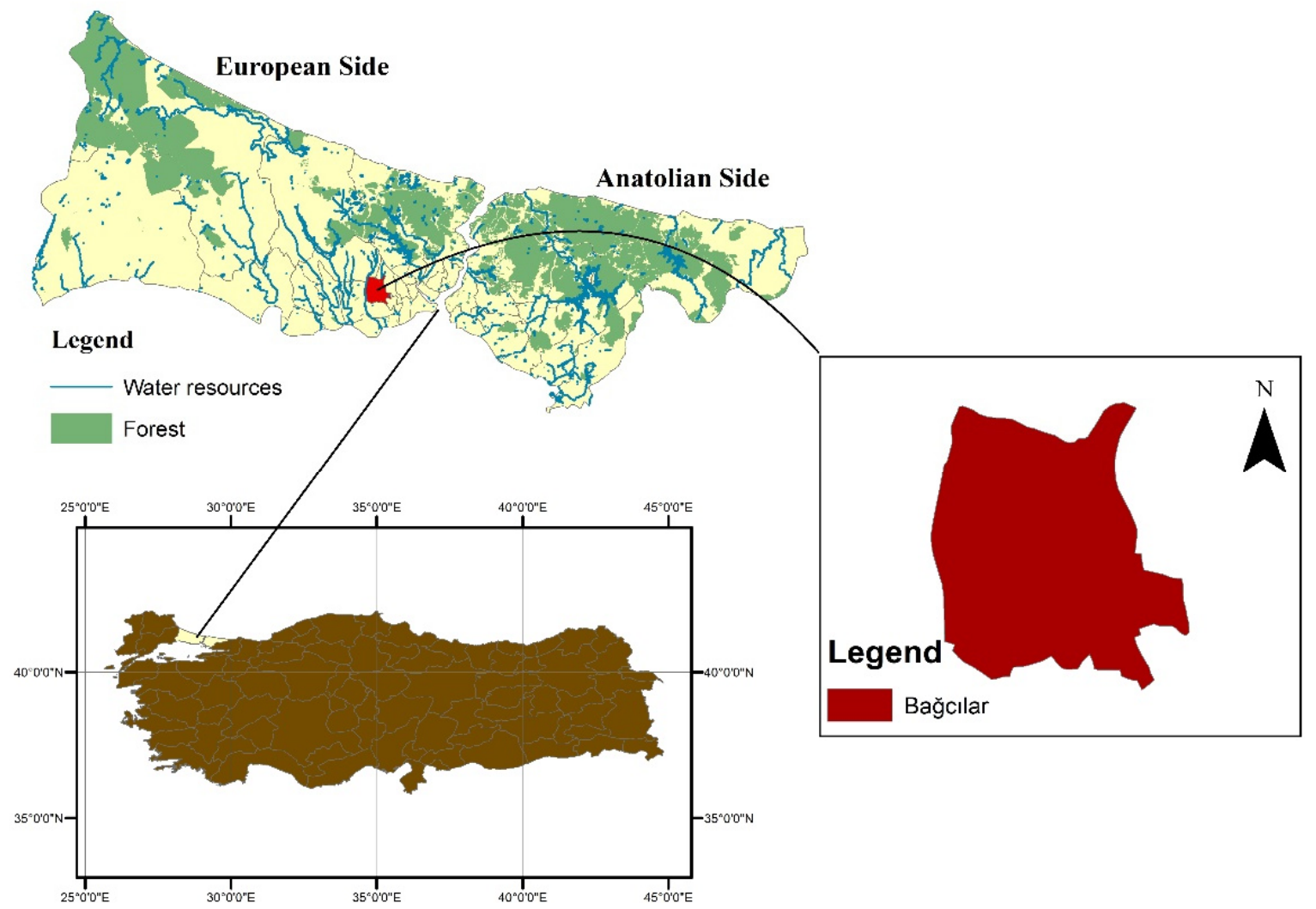

Figure 3. Study area.

\subsection{Defining the Evaluation Criteria}

Evaluation criteria were determined with the suggestions of the advisory board consisting of academicians and experts. Academicians represent the authors of the study, while experts represent healthcare professionals and city planners. In this study, a site selection analysis was carried out by considering eight criteria.

The considered criteria are; road networks, public transportation stops (PTS), emergency stations, hospitals, pharmacies, population, buildings, and police stations. Explanations and sources of criteria are given in Table 2.

One of the most used criteria in site selection problems is "land and construction cost". However, this criterion was not considered in this study, since the purpose of establishing vaccination centres is not commercial.

Since Bağcllar district was selected as the study area in the paper, the data of the evaluation criteria were taken into consideration for Bağcılar district boundaries. 
Table 2. Explanation and data source of evaluation criteria.

\begin{tabular}{|c|c|c|c|}
\hline Criterion & Explanation & Data Source & Type of Analysis \\
\hline Road networks & $\begin{array}{l}\text { Considering all road networks of the district, } \\
\text { vaccination centers should be designed to serve } \\
\text { the entire district in terms of transportation. For } \\
\text { this reason, it is thought that vaccination centers } \\
\text { close to road networks will be more efficient. }\end{array}$ & $\begin{array}{c}\text { https:/ /uym.ibb.gov.tr/YHarita/ } \\
\text { Harita_tr.aspx (Accessed Date: } 5 \\
\text { April 2021) }\end{array}$ & Euclidean Distance \\
\hline PTS & $\begin{array}{l}\text { Since vehicle mobility is high at PTS points, it } \\
\text { will be appropriate to perform vaccination in } \\
\text { these regions. Therefore, proximity to these } \\
\text { regions is important in analysis. The district has } \\
\text { 110. Since it is thought that not everyone has a } \\
\text { private vehicle, individuals who want to be } \\
\text { vaccinated should be able to reach vaccination } \\
\text { centers by public transport. }\end{array}$ & $\begin{array}{c}\text { https://www.iett.istanbul/tr/ } \\
\text { main/hatlar/ (Accessed Date: } 6 \\
\text { April 2021) }\end{array}$ & Euclidean Distance \\
\hline $\begin{array}{l}\text { Emergency } \\
\text { stations }\end{array}$ & $\begin{array}{l}\text { In case of an emergency in the vaccination } \\
\text { centers, its proximity to these regions is } \\
\text { important in order to intervene fast. The district } \\
\text { has nine. Considering that there are still } \\
\text { suspicions for the side effects of vaccines and } \\
\text { studies are ongoing, proximity to emergency } \\
\text { stations is important for patient health in case of } \\
\text { an unexpected side effect. }\end{array}$ & $\begin{array}{l}\text { https:/ / bagcilar.istanbulsaglik. } \\
\text { gov.tr/hakkinda/sayisalbilgiler } \\
\text { (Accessed Date: } 7 \text { April 2021) }\end{array}$ & Euclidean Distance \\
\hline Hospitals & $\begin{array}{l}\text { In case of a phenomenal situation (side effect) in } \\
\text { vaccination centers, infected people should be } \\
\text { transferred to hospitals and the proximity of } \\
\text { these centers to hospitals is important for } \\
\text { analysis. The district has } 20 .\end{array}$ & $\begin{array}{l}\text { https:/ / bagcilar.istanbulsaglik. } \\
\text { gov.tr/hakkinda/hastaneler } \\
\text { (Accessed Date: } 10 \text { April 2021) }\end{array}$ & Euclidean Distance \\
\hline Pharmacies & $\begin{array}{l}\text { Proximity to pharmacies is important to meet the } \\
\text { medical material needs that may occur in } \\
\text { vaccination centers. The district has } 99 .\end{array}$ & $\begin{array}{l}\text { https:/ / www.eczaneler.gen.tr/ } \\
\text { eczaneler/istanbul-bagcilar } \\
\text { (Accessed Date: } 11 \text { April 2021) }\end{array}$ & Euclidean Distance \\
\hline Population & $\begin{array}{l}\text { It is very important to establishment vaccination } \\
\text { centers in these regions, as the mobility and } \\
\text { contact are high in dense populations. In } \\
\text { addition, vaccination centers will play an } \\
\text { important role in meeting the demand for } \\
\text { vaccines in densely populated areas. }\end{array}$ & $\begin{array}{l}\text { http:/ / www.tuik.gov.tr/ } \\
\text { PreIstatistikTablo.do?istab_id=22 } \\
0 \text { (Accessed Date: } 7 \text { April 2021) }\end{array}$ & Kernel Density \\
\hline Buildings & $\begin{array}{l}\text { Since the mobility between the settlement areas } \\
\text { is high, the siting of vaccination centers in these } \\
\text { areas is very important for case diagnosis and } \\
\text { thus the efficiency of these centers will } \\
\text { be increased. }\end{array}$ & $\begin{array}{l}\text { https:/ / sehirharitasi.ibb.gov.tr/ } \\
\text { (Accessed Date: } 5 \text { May 2021) }\end{array}$ & Euclidean Distance \\
\hline Police stations & $\begin{array}{l}\text { Proximity of the police stations against any } \\
\text { security problems (the desire of infected people } \\
\text { to escape, discussion, fighting etc.) that may } \\
\text { occur in vaccination centers is important for the } \\
\text { intervention. The district has six. }\end{array}$ & $\begin{array}{l}\text { https://www.egm.gov.tr/en- } \\
\text { yakin-polis-merkezi (Accessed } \\
\text { Date: } 7 \text { April 2021) }\end{array}$ & Euclidean Distance \\
\hline
\end{tabular}

The evaluation criteria are presented in Figure 4 by creating awareness. In this regard, a study package with eight criteria was created in the study. 


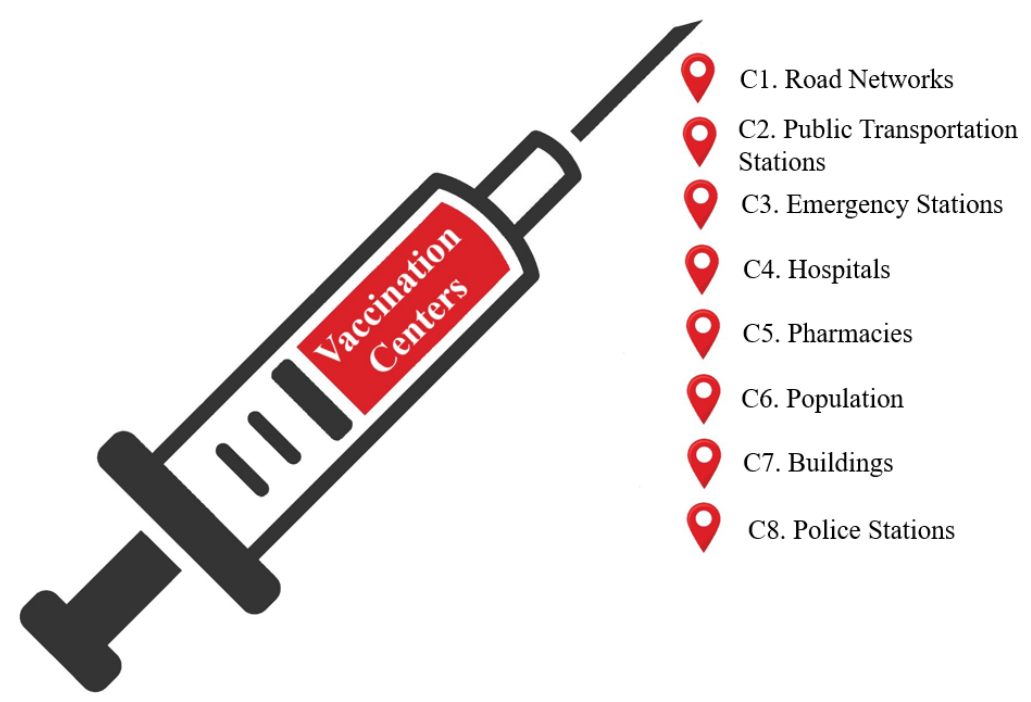

Figure 4. Evaluation criteria for vaccination centre.

\section{Methods}

In the literature, GIS and MCDA approaches are frequently preferred in solving site selection problems. In this study, a hybrid approach was used because determining the most suitable locations of vaccination centres is a site selection and a multi-criteria decisionmaking problem. The combination of GIS and MDCA techniques enables a strong scientific framework for decision-makers.

In this study, the AHP method was preferred for the weighting of the criteria. Usability, strong structure, and efficiency on criterion weighting of AHP has been proven by various studies. For the spatial analysis of the criteria, GIS, which is frequently used in the solution of site selection problems, was used. In recent years, MCDA methods and GIS have become increasingly popular as a tool for the solution of different site selection studies. A brief description of the proposed methodology is given below.

\subsection{Analytic Hierarchy Process}

The AHP method is a mathematical technique developed by T. Saaty in 1977 for the process of weighting criteria in multi-criteria decision-making problems [63]. In addition, it is the most used MCDA method in the analysis of complex decisions in recent years. In order to determine the superiorities of each criterion relative to each other, pairwise comparison matrices are created by asking the " which criteria are more important to solve problem" question to the decision-makers. Saaty's [1-9] scale is used in comparison matrices to compare the superiority of the criteria. The consistency of the comparison matrices is determined by the consistency ratio (CR). If this ratio is less than 0.10 , it proves that the calculated criteria weights can be used. AHP calculation steps generally consist of five steps.

Step 1. Definition of a multi-criteria problem

Step 2. Constructing the hierarchy

The criteria to be used in the hierarchy are benefited from literature review, survey study, expert's opinions.

Step 3. Constructing pairwise comparison matrices

In the creation of pairwise comparison matrices, the question "which criterion is more important to the solve problem?" is presented. These matrices are obtained by using the Saaty scale according to the given answers.

Step 4. Normalisation of pairwise comparison matrices 
Matrices are normalised between 0-1 using Equation (1) in terms of the homogeneity of pairwise comparison matrices. Although there are various normalisation formulations in the literature, vector normalisation given in Equation (1) is used in the AHP.

$$
a_{i j}^{\prime}=\frac{a_{i j}}{\sum_{i=1}^{n} a_{i j}}
$$

Step 5. Calculation of the consistency ratio

To measure the consistency of pairwise comparison matrices, the consistency ratio formula expressed in Equation (2) is used.

$$
C R=\frac{C I}{R I}
$$

The consistency index (CI) variable in Equation (2) is given in Equation (3). The Random Index $(R I)$ variable varies according to the number of considered criteria, and the relevant values are presented in Table 3.

$$
C I=\lambda_{\max }-\frac{n}{n-1}
$$

$a_{i j}$ : decision alternatives; $\lambda_{\max }$ : eigenvalue.

Table 3. Random Index table values [64].

\begin{tabular}{ccccccccccc}
\hline $\boldsymbol{n}$ & $\mathbf{1}$ & $\mathbf{2}$ & $\mathbf{3}$ & $\mathbf{4}$ & $\mathbf{5}$ & $\mathbf{6}$ & $\mathbf{7}$ & $\mathbf{8}$ & $\mathbf{9}$ & $\mathbf{1 0}$ \\
\hline $\boldsymbol{R I}$ & 0 & 0 & 0.52 & 0.89 & 1.11 & 1.25 & 1.35 & 1.40 & 1.45 & 1.49 \\
\hline
\end{tabular}

\subsection{Geographical Information Systems}

GIS are systems that enable a spatial analysis to be performed [65]. The data is collected, processed, stored, and analysed using these systems. While performing GIS analysis, maps called layers are used. The numerical data processed on the layers are divided into two as vector and raster data [66].

Today, GIS stands out as one of the systems that are frequently applied in many areas such as health data visualisation, meteorological analysis, transportation planning, water resources management, military, and strategic applications, management processes [67-69]. It is a big advantage that GIS is easy to apply and that the results of the analyses can be reported both numerically and visually. This advantage has made GIS a platform that is frequently used and has a wide application area.

Merging of layer on which point and line data, raster data, elevation data, and all other spatial data are processed is defined as layer overlapping. Different types of geographic data need to be standardised before layer overlapping. Layer weights can be assigned to the layers of standardised data. Weighted layers of standardised data can also be overlapped, processed, and visualised in a GIS environment.

\section{Results}

Various studies have been continued to reduce the impact of the health, social and economic crisis caused by the pandemic as much as possible. There are many medical studies in the field of health (drugs, diagnosis of positive cases, rehabilitation of patients, vaccines), as well as studies against the pandemic in other disciplines $[9,39,70,71]$. After the vaccine, which is shown as a treatment for the COVID-19 virus, many important problems occur that need to be solved. These can be shown in vaccine studies that concern both health and other disciplines, vaccine storage, vaccine logistics and distribution, vaccine administration, and vaccine accessibility.

In this study, vaccine accessibility by everyone was analysed in terms of transportation, health, demographic, settlement, and security. Locating the most suitable vaccination 
centres was discussed scientifically and strategically. Thus, the faster and healthier running of the vaccine programme will ensure a great contribution to the fight against the pandemic.

A scientific framework was proposed using the GIS-based MCDA technique in order to provide the foresighted contribution in this paper. First, eight criteria that are thought to affect the locations of vaccination centres were determined with the recommendations and experiences of the advisory board. The weighting of the criteria was performed with AHP. Pairwise comparison matrices were used to determine the criterion weights. First, the decision-maker team (advisory board) was formed to obtain the pairwise comparison matrices. The decision-maker team consists of six people from academicians in the field of transportation, health, city planner (department of transportation, health. and city planner), and experts from the Ministry of Health. Each member of the decision-maker team created pairwise comparison matrices to determine the weight of the criteria over each other. After examining the Consistency Ratios of all pairwise comparison matrices, the final criterion weights were obtained by taking the average of the obtained weights. The CR ratio, which indicates that the criterion weights are valid, was found to be 0.0705 value. Criteria weights are presented in Table 4. For simplicity, calculation steps of the AHP method were not presented. However, calculation steps are available upon request.

Table 4. Weight of evaluation criteria.

\begin{tabular}{ccccccccc}
\hline Criterion & $\begin{array}{c}\text { Road } \\
\text { Networks }\end{array}$ & PTS & $\begin{array}{c}\text { Emergency } \\
\text { Stations }\end{array}$ & Hospitals & Pharmacies & Population & Buildings & $\begin{array}{c}\text { Police } \\
\text { Station }\end{array}$ \\
\hline Weights & 0.2123 & 0.0488 & 0.0714 & 0.2123 & 0.0236 & 0.3501 & 0.0555 & 0.0261 \\
\hline
\end{tabular}

The negative impact of the population on the spread of the pandemic is enormous. The spread of the COVID-19 virus is accelerating due to close contact and high mobility in regions with high populations. As it is clear from Table 4, the criterion that most affects the vaccination centres is C6. Population.

In addition, the second most important criterion affecting the locations of vaccination centres is C1. Road Networks, which affects the accessibility of the target group to vaccination centres. While determining the location of vaccination centres, C5. Pharmacies, where the necessary medical equipment can be supplied, were evaluated as the least important criterion. The obtained criterion weights were used for spatial analysis.

Transferring and processing the criteria data to the GIS environment plays an important role in determining vaccination centres. In addition, the accuracy and reliability of the criteria data and resources directly affect the study. The authors are very sensitive about the data collection process. The collected data were transferred to GIS and Kernel density/Euclidean distance spatial analyses were applied in accordance with each criterion. Then, the normalisation process was applied as the [0-1] scale for the homogeneity and integrity of the criterion data, and the normalisation maps are presented in Figure 5.

When Figure 5 is examined, white areas represent the most suitable areas for the population criterion map. For all other criteria, the black areas indicate the most suitable areas. Reclassify spatial analysis was performed to ensure consistency of criteria before the overlapping process. Overlapping analysis of eight criteria was carried out with the help of weighted overlay analysis.

To summarise briefly, GIS analysis consists of six steps: data collection, transfer of data to GIS, visual analysis, normalisation, reclassify and weighted overlay. Criteria weights obtained from AHP were used for these analyses. As a result, a suitability map was obtained to determine the most suitable locations of vaccination centres. The map is given in Figure 6.

The suitability map was divided into 10 classes and the red areas represent the most suitable areas, while the green areas represent the least suitable areas. It is seen that the red areas are clustered in three different areas. To do so, an assignment process was made for the establishment of three vaccination centres. In addition, Thiessen Polygon was used 
to determine the service areas of the assigned vaccination centres throughout the district. The assigned vaccination centres and service areas are given in Figure 7. Thus, it is clearly stated which vaccination centre the target group in Bağclar district will receive service from. A healthier and faster vaccination programme is possible by preventing unwanted crowding in vaccination centres.

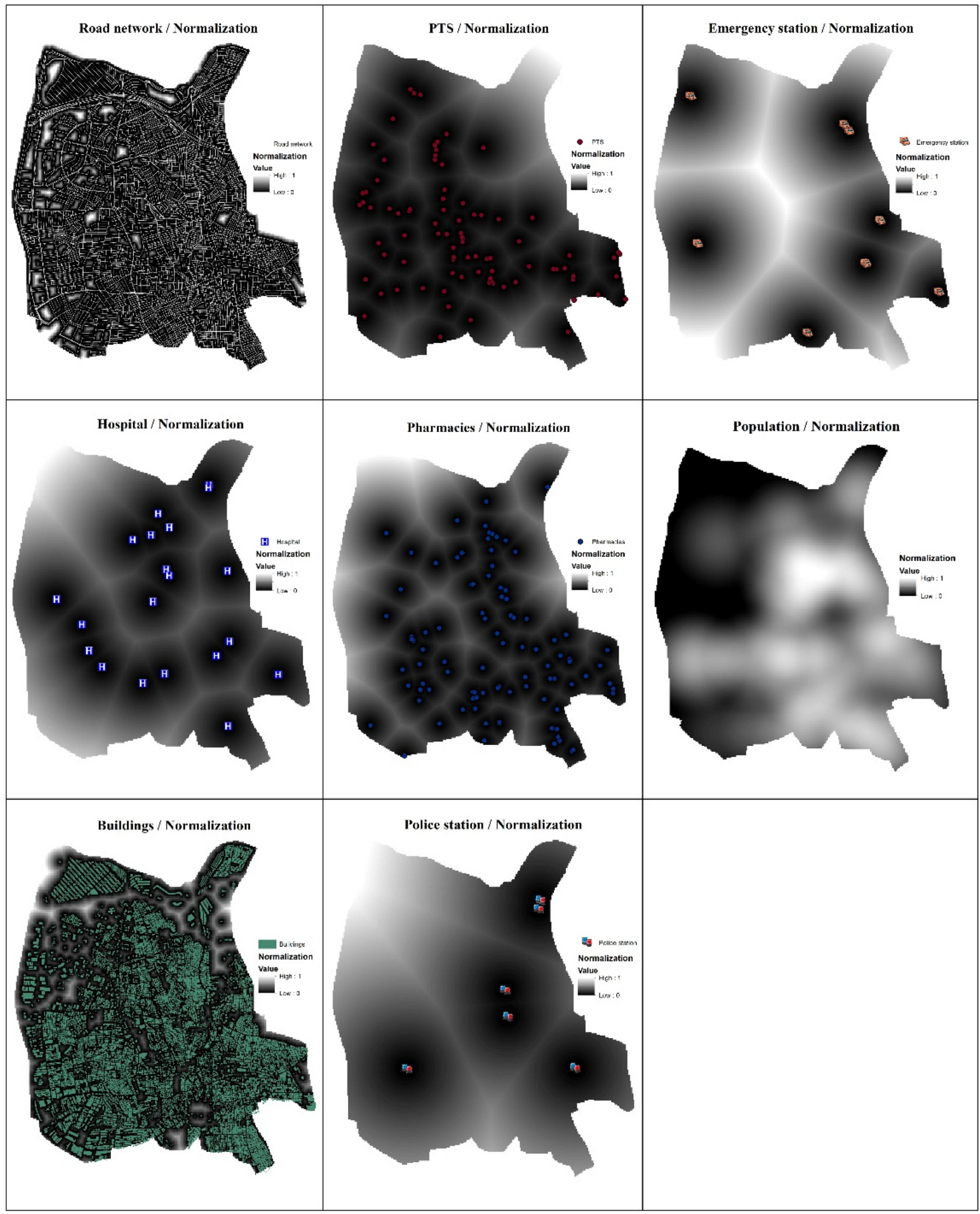

Figure 5. GIS layer of each criteria. 


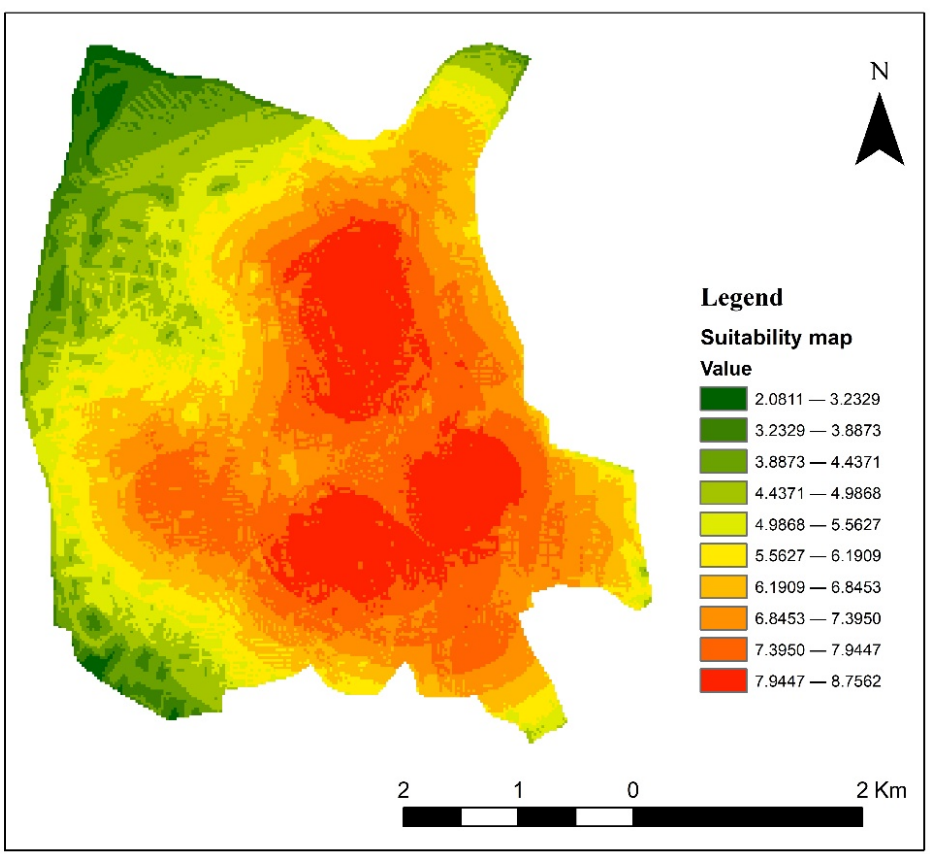

Figure 6. Suitability map for the vaccination centres.
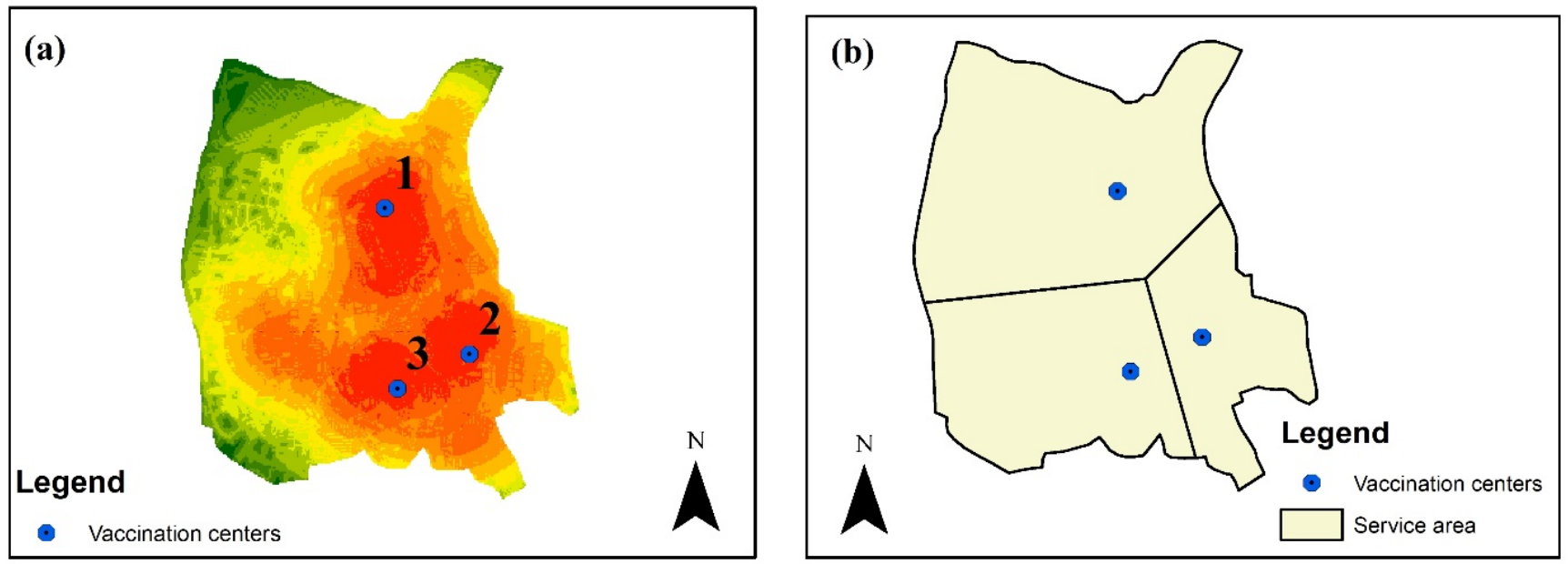

Figure 7. Suitability map for the vaccination centres (a) assigned vaccination centres (b) service areas of vaccination centres.

Sensitivity analysis was applied to measure the effects of the criteria on vaccination centre locations. Six different scenarios were created by changing the criterion weights. In all scenarios, the sum of criterion weights is one.

- Scenario 1 is current condition of criteria weights.

- Scenario 2, the weight of $\mathrm{C} 1$ and $\mathrm{C} 2$ criteria is decreased by $75 \%$.

- Scenario 3, the weight of C3 and C4 criteria is decreased by $75 \%$.

- Scenario 4 , the weight of $\mathrm{C} 5$ and $\mathrm{C} 6$ criteria is decreased by $75 \%$.

- Scenario 5 , the weight of $\mathrm{C} 7$ and C8 criteria is decreased by $75 \%$.

- Scenario 6, weights of all criteria are equal.

All spatial analyses for each scenario were re-made and suitability maps for each scenario were obtained. These maps are presented in Figure 8. 


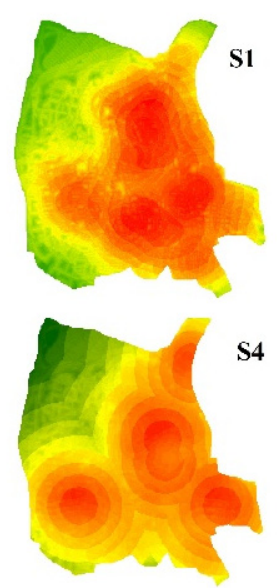

Legend

Suitability map

Best Suitable Areas

Least Suitable Areas
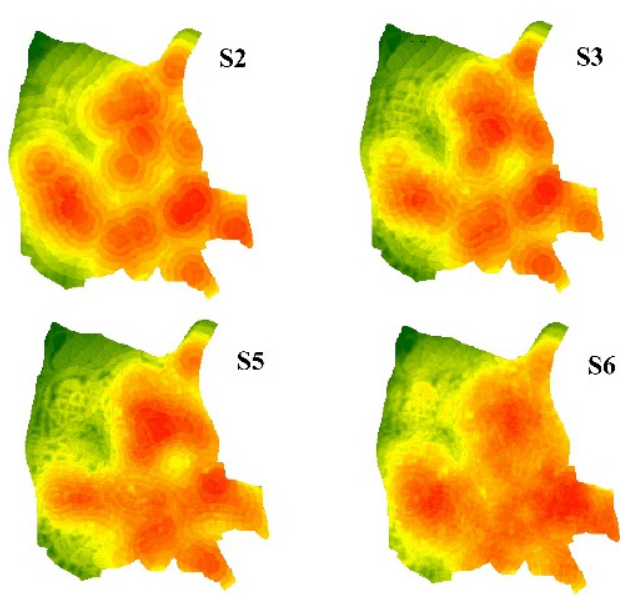

$\mathbf{S 3}$

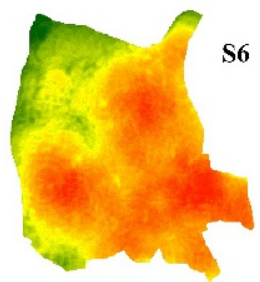

$\mathrm{N}$

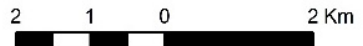

Figure 8. Sensitivity analysis of suitability map.

When the changes in the obtained suitability maps are examined, it is seen that the results are quite sensitive. Especially, the most change is seen in scenarios 2 and 4 . The reason for this is the effect of the population and road networks, which are the two most important criteria in current condition, on the results.

\section{Discussion}

In this section, we analysed the findings according to the proposed methodology. When we examined the suitability map, it is seen that the suitable areas are clustered in three different areas.

The geographic positions in terms of population, hospital, police stations, PTS, and pharmacies of these suitable areas is the most important explanation for suitability. Three vaccination centres were assigned due to the clustering in three different areas. The efficiency, accessibility, availability, and security of the centres level will be increased with the assignment of vaccination centres to the most suitable areas. The service areas of the assigned vaccination centres were determined, and it has been planned for the target group to receive accessibility to the relevant centre. Increasing the contribution level of proposed methodology should be implemented in the Istanbul first and then the whole country.

The vaccination programme is currently expressed as a key part of outbreak control/management.

One of the most important components of this programme is the location of vaccination centres. Lack of any scientific analysis in the positioning of these centres and the slightest mishaps in the vaccination programme will create big problems in this programme.

The next steps in defining the vaccination process and the location of the administration areas can be defined and controlled through the creation of databases and GIS maps contributing to the development of what is described in Figure 9. 


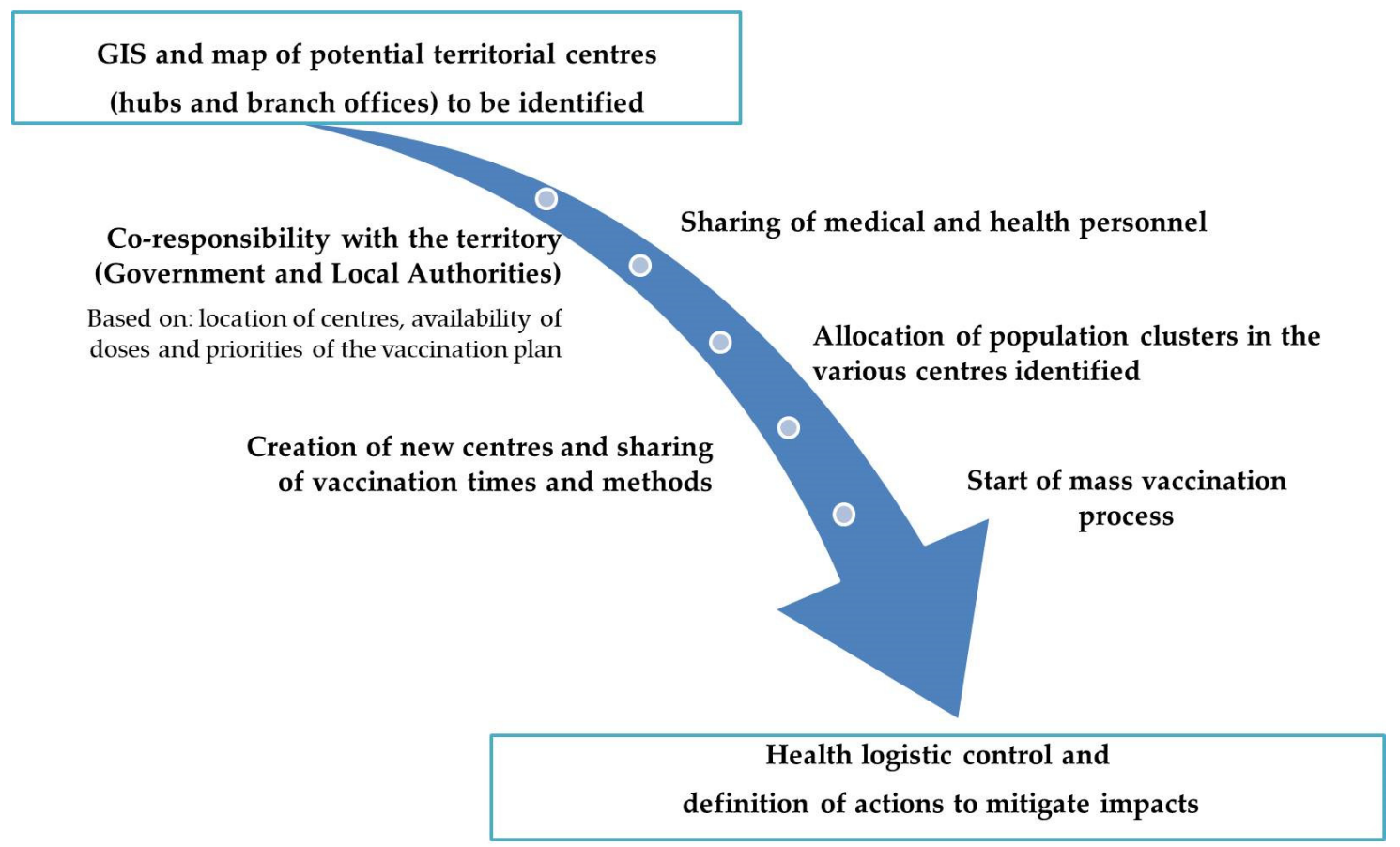

Figure 9. The development of GIS maps for the mitigation impacts of logistics post COVID-19 era.

This study, which aims to minimise these problems, is a guideline study. In addition, a significant contribution will be ensuring the establishment of vaccine centres for authorised institutions of states and other stakeholders.

There are several issues to be discussed in this paper. Due to no current vaccination centres studies, the number of evaluation criteria in this study was limited to eight. The survey (which could not be performed due to the pandemic) can be conducted to the target group, health workers, and city planner and a more comprehensive analysis can be provided in the location of the vaccination centres. In this way, the limited number of criteria can be increased thanks to the survey. The paper provides a scientific solution to the infrastructure problem occurring from the pandemic and vaccination programme.

The geolocalisation of the hubs is also of fundamental importance for the definition and organisation of the methods and applications for recording and tracing vaccine data (data linked to the structure, the medical and health personnel, the type of vaccine, and the patient).

In addition, the creation of GIS mappers allows the definition and planning of the monitoring of the vaccination campaign and the evaluation of adherence and coverage, as well as the monitoring of adverse reaction reports, especially if different databases are integrated, thus defining a multi-criteria and multi-disciplinary system.

\section{Conclusions}

The COVID-19 outbreak had a noticeable effect on lifestyle, healthcare sector, health workers, and travel behavior during recent months. Vaccination is the most important method to quickly eliminate the impact of the pandemic. It is inevitable to establish vaccination centres outside of hospitals for the vaccine to be administered to most people. The vaccination centres site selection is an important problem in the vaccination programme. Thus, in this study, we focused on developing a scientific and strategic spatial decision support method. To do so, a three-step approach was developed using a GIS-based MCDA technique. In the site selection analysis process, eight criteria were considered in terms of transportation, health, demographic, settlement, and security. The evaluation criteria were weighted and the spatial analyses were performed using AHP and GIS methods, respectively. As a result of this process, a suitability map for the locations of vaccination 
centres was obtained. "Best suitable" areas are clustered in three different areas in the suitability map. Potential vaccination centres were assigned to the "best suitable" areas and the service areas of these centres were determined via Thiessen Polygons.

This paper is a guide for policymakers and other stakeholders who want to establish vaccination centres in the world. Different criteria may be added to be considered for the solution of the site selection problem of vaccination centres in different cities/countries. The proposed scientific and strategic methodology can be easily applied for different cities/countries. To summarise, the proposed methodology provides the opportunity to run a scientific and strategic vaccination programme and create the possibility of a suitable vaccination centres map for countries.

The coordination and planning of procurement activities, storage, distribution, and monitoring of the availability of vaccine doses, as well as the setting up of ad hoc vaccination sites and points, are the next points of analysis in the next steps of this research.

Author Contributions: Conceptualization, Ömer Kaya and Kadir Diler Alemdar; methodology, Ömer Kaya and Kadir Diler Alemdar; software, Ömer Kaya and Kadir Diler Alemdar; validation, Ömer Kaya and Kadir Diler Alemdar and Tiziana Campisi; formal analysis, Muhammed Yasin Çodur; investigation, Ömer Kaya and Kadir Diler Alemdar; resources, Ömer Kaya and Kadir Diler Alemdar; data curation, Ömer Kaya and Kadir Diler Alemdar and Muhammed Yasin Çodur; writing_original draft preparation, Ömer Kaya, Kadir Diler Alemdar and Tiziana Campisi; writing-review and editing, Ömer Kaya, Kadir Diler Alemdar, Muhammed Yasin Çodur and tiziana campisi; visualization, Tiziana Campisi; supervision, Giovanni Tesoriere and Tiziana Campisi; project administration, Muhammed Yasin Çodur; funding acquisition, Tiziana Campisi and Giovanni Tesoriere. All authors have read and agreed to the published version of the manuscript.

Funding: This research received no external funding.

Institutional Review Board Statement: Not applicable.

Informed Consent Statement: Not applicable.

Data Availability Statement: Data available in a publicly accessible repository.

Conflicts of Interest: The authors declare no conflict of interest.

\section{References}

1. Gandhi, M.; Havlir, D. The time for universal masking of the public for coronavirus disease 2019 is now. Open Forum Infect. Dis. 2020, 7, 1-4. [CrossRef]

2. Notari, A. Temperature dependence of COVID-19 transmission. Sci. Total Environ. 2021, 763, 144390. [CrossRef] [PubMed]

3. Tiejun, Z. Implementation Status and Development Thinking on "Cloud National Examination" in China under the situation of "Online Anti-COVID-19 Epidemic". Technol. Forecast. Soc. Chang. 2021, 162, 120322. [CrossRef] [PubMed]

4. Fernández Cruz, M.; Álvarez Rodríguez, J.; Ávalos Ruiz, I.; Cuevas López, M.; de Barros Camargo, C.; Díaz Rosas, F.; González Castellón, E.; González González, D.; Hernández Fernández, A.; Ibáñez Cubillas, P.; et al. Evaluation of the Emotional and Cognitive Regulation of Young People in a Lockdown Situation Due to the COVID-19 Pandemic. Front. Psychol. 2020, 11, 565503. [CrossRef] [PubMed]

5. Liu, Q.; Zhou, Y.; Xie, X.; Xue, Q.; Zhu, K.; Wan, Z.; Wu, H.; Zhang, J.; Song, R. The prevalence of behavioral problems among school-aged children in home quarantine during the COVID-19 pandemic in China. J. Affect. Disord. 2021, 279, 412-416. [CrossRef]

6. Amit Aharon, A.; Dubovi, I.; Ruban, A. Differences in mental health and health-related quality of life between the Israeli and Italian population during a COVID-19 quarantine. Qual. Life Res. 2021, 30, 1675-1684. [CrossRef]

7. Santana, F.N.; Hammond Wagner, C.; Berlin Rubin, N.; Bloomfield, L.S.P.; Bower, E.R.; Fischer, S.L.; Santos, B.S.; Smith, G.E.; Muraida, C.T.; Wong-Parodi, G. A path forward for qualitative research on sustainability in the COVID-19 pandemic. Sustain. Sci. 2021, 16, 1061-1067. [CrossRef]

8. Epifanio, M.S.; Andrei, F.; Mancini, G.; Agostini, F.; Piombo, M.A.; Spicuzza, V.; Riolo, M.; Lavanco, G.; Trombini, E.; La Grutta, S. The Impact of COVID-19 Pandemic and Lockdown Measures on Quality of Life among Italian General Population. J. Clin. Med. 2021, 10, 289. [CrossRef]

9. Zolfani, S.H.; Yazdani, M.; Torkayesh, A.E.; Derakhti, A. Application of a gray-based decision support framework for location selection of a temporary hospital during COVID-19 pandemic. Symmetry 2020, 12, 886. [CrossRef]

10. Murgante, B.; Balletto, G.; Borruso, G.; Casas, G.L.; Castiglia, P.; Dettori, M. Geographical analyses of COVID-19's spreading contagion in the challenge of global health risks. TeMA J. Land Use Mobil. Environ. 2020. [CrossRef] 
11. Dettori, M.; Deiana, G.; Balletto, G.; Borruso, G.; Murgante, B.; Arghittu, A.; Azara, A.; Castiglia, P. Air pollutants and risk of death due to COVID-19 in Italy. Environ. Res. 2021, 192, 110459. [CrossRef]

12. Rawat, K.; Kumari, P.; Saha, L. COVID-19 vaccine: A recent update in pipeline vaccines, their design and development strategies. Eur. J. Pharmacol. 2021, 892, 173751. [CrossRef]

13. Maqbool, A.; Khan, N.Z. Analyzing barriers for implementation of public health and social measures to prevent the transmission of COVID-19 disease using DEMATEL method. Diabetes Metab. Syndr. Clin. Res. Rev. 2020, 14, 887-892. [CrossRef] [PubMed]

14. Li, D.D.; Li, Q.H. SARS-CoV-2: Vaccines in the pandemic era. Mil. Med Res. 2021, 8, 1-15. [CrossRef] [PubMed]

15. Divu, D.N.; Mojjada, S.K.; Pokkathappada, A.A.; Sukhdhane, K.; Menon, M.; Mojjada, R.K.; Tade, M.S.; Bhint, H.M.; Gopalakrishnan, A. Decision-making framework for identifying best suitable mariculture sites along north east coast of Arabian Sea, India: A preliminary GIS-MCE based modelling approach. J. Clean. Prod. 2021, 284, 124760. [CrossRef]

16. Ağaçsapan, B.; Çabuk, S.N. Determination of suitable waste transfer station areas for sustainable territories: Eskisehir case. Sustain. Cities Soc. 2020, 52, 101829. [CrossRef]

17. Feyzi, S.; Khanmohammadi, M.; Abedinzadeh, N.; Aalipour, M. Multi- criteria decision analysis FANP based on GIS for siting municipal solid waste incineration power plant in the north of Iran. Sustain. Cities Soc. 2019, 47, 101513. [CrossRef]

18. Bertram, D.V.; Tarighaleslami, A.H.; Walmsley, M.R.W.; Atkins, M.J.; Glasgow, G.D.E. A systematic approach for selecting suitable wave energy converters for potential wave energy farm sites. Renew. Sustain. Energy Rev. 2020, 132, 110011. [CrossRef]

19. Lindberg, O.; Birging, A.; Widén, J.; Lingfors, D. PV park site selection for utility-scale solar guides combining GIS and power flow analysis: A case study on a Swedish municipality. Appl. Energy 2021, 282, 116086. [CrossRef]

20. Afzali, A.; Sabri, S.; Rashid, M.; Mohammad Vali Samani, J.; Ludin, A.N.M. Inter-Municipal Landfill Site Selection Using Analytic Network Process. Water Resour. Manag. 2014, 28, 2179-2194. [CrossRef]

21. Davtalab, M.; Alesheikh, A.A. Spatial optimization of biomass power plant site using fuzzy analytic network process. Clean Technol. Environ. Policy 2018, 20, 1033-1046. [CrossRef]

22. Fahad, M.G.R.; Nazari, R.; Bhavsar, P.; Jalayer, M.; Karimi, M. A decision-support framework for emergency evacuation planning during extreme storm events. Transp. Res. Part D Transp. Environ. 2019, 77, 589-605. [CrossRef]

23. Kaya, Ö.; Alemdar, K.D.; Çodur, M.Y. A novel two stage approach for electric taxis charging station site selection. Sustain. Cities Soc. 2020, 62, 102396. [CrossRef]

24. Mrak, I.; Campisi, T.; Sanja, Š.; Errigo, M.F. MCDM evaluation in GIS system for evaluating the pedestrian and alternative paths in Rijeka. AIP Conf. Proc. 2021, 2343, 090004.

25. Nyimbili, P.H.; Erden, T.; Karaman, H. Integration of GIS, AHP and TOPSIS for earthquake hazard analysis. Nat. Hazards 2018, 92, 1523-1546. [CrossRef]

26. Trivedi, A.; Singh, A. A hybrid multi-objective decision model for emergency shelter location-relocation projects using fuzzy analytic hierarchy process and goal programming approach. Int. J. Proj. Manag. 2017, 35, 827-840. [CrossRef]

27. Alemdar, K.D.; Kaya, Ö.; Canale, A.; Çodur, M.Y.; Campisi, T. Evaluation of Air Quality Index by Spatial Analysis Depending on Vehicle Traffic during the COVID-19 Outbreak in Turkey. Energies 2021, 14, 5729. [CrossRef]

28. Balew, A.; Alemu, M.; Leul, Y.; Feye, T. Suitable landfill site selection using GIS-based multi-criteria decision analysis and evaluation in Robe town, Ethiopia. GeoJournal 2020. [CrossRef]

29. Wang, J.; Tsai, C.H.; Lin, P.C. Applying spatial-temporal analysis and retail location theory to pubic bikes site selection in Taipei. Transp. Res. Part A Policy Pract. 2016, 94, 45-61. [CrossRef]

30. Atici, K.B.; Simsek, A.B.; Ulucan, A.; Tosun, M.U. A GIS-based Multiple Criteria Decision Analysis approach for wind power plant site selection. Util. Policy 2015, 37, 86-96. [CrossRef]

31. Uyan, M. Optimal site selection for solar power plants using multi-criteria evaluation: A case study from the Ayranci region in Karaman, Turkey. Clean Technol. Environ. Policy 2017, 19, 2231-2244. [CrossRef]

32. Alemdar, K.D.; Kaya, Ö.; Çodur, M.Y. A GIS and microsimulation-based MCDA approach for evaluation of pedestrian crossings. Accid. Anal. Prev. 2020, 148, 105771. [CrossRef]

33. Campisi, T.; Basbas, S.; Tesoriere, G.; Trouva, M.; Papas, T.; Mrak, I. How to Create Walking Friendly Cities. A Multi-Criteria Analysis of the Central Open Market Area of Rijeka. Sustainability 2020, 12, 9470. [CrossRef]

34. Ortega, J.; Moslem, S.; Palaguachi, J.; Ortega, M.; Campisi, T.; Torrisi, V. An Integrated Multi Criteria Decision Making Model for Evaluating Park-and-Ride Facility Location Issue: A Case Study for Cuenca City in Ecuador. Sustainability 2021, $13,7461$. [CrossRef]

35. Song, S.; Zhou, H.; Song, W. Sustainable shelter-site selection under uncertainty: A rough QUALIFLEX method. Comput. Ind. Eng. 2019, 128, 371-386. [CrossRef]

36. Lin, C.T.; Tsai, M.C. Location choice for direct foreign investment in new hospitals in China by using ANP and TOPSIS. Qual. Quant. 2010, 44, 375-390. [CrossRef]

37. Erbaş, M.; Kabak, M.; Özceylan, E.; Çetinkaya, C. Optimal siting of electric vehicle charging stations: A GIS-based fuzzy Multi-Criteria Decision Analysis. Energy 2018, 163, 1017-1031. [CrossRef]

38. Kutlu Gündoğdu, F.; Kahraman, C.; Civan, H.N. A novel hesitant fuzzy EDAS method and its application to hospital selection. J. Intell. Fuzzy Syst. 2018, 35, 6353-6365. [CrossRef]

39. Senvar, O.; Otay, I.; Bolturk, E. Hospital Site Selection via Hesitant Fuzzy TOPSIS. IFAC-PapersOnLine 2016, 49, 1140-1145. [CrossRef] 
40. Aydin, N.Y.; Kentel, E.; Sebnem Duzgun, H. GIS-based site selection methodology for hybrid renewable energy systems: A case study from western Turkey. Energy Convers. Manag. 2013, 70, 90-106. [CrossRef]

41. Mishra, A.K.; Deep, S.; Choudhary, A. Identification of suitable sites for organic farming using AHP \& GIS. Egypt. J. Remote Sens. Space Sci. 2015, 18, 181-193. [CrossRef]

42. Kaya, Ö.; Tortum, A.; Alemdar, K.D.; Çodur, M.Y. Site selection for EVCS in Istanbul by GIS and multi-criteria decision-making. Transp. Res. Part D Transp. Environ. 2020, 80, 102271. [CrossRef]

43. Xu, J.; Zhong, L.; Yao, L.; Wu, Z. An interval type-2 fuzzy analysis towards electric vehicle charging station allocation from a sustainable perspective. Sustain. Cities Soc. 2018, 40, 335-351. [CrossRef]

44. Tu, W.; Li, Q.; Fang, Z.; Shaw, S.L.; Zhou, B.; Chang, X. Optimizing the locations of electric taxi charging stations: A spatialtemporal demand coverage approach. Transp. Res. Part C Emerg. Technol. 2016, 65, 172-189. [CrossRef]

45. Lin, M.; Huang, C.; Xu, Z. MULTIMOORA based MCDM model for site selection of car sharing station under picture fuzzy environment. Sustain. Cities Soc. 2020, 53, 101873. [CrossRef]

46. Deveci, M.; Canıtez, F.; Gökaşar, I. WASPAS and TOPSIS based interval type-2 fuzzy MCDM method for a selection of a car sharing station. Sustain. Cities Soc. 2018, 41, 777-791. [CrossRef]

47. Özceylan, E.; Çetinkaya, C.; Erbaş, M.; Kabak, M. Logistic performance evaluation of provinces in Turkey: A GIS-based multi-criteria decision analysis. Transp. Res. Part A Policy Pract. 2016, 94, 323-337. [CrossRef]

48. Kabak, M.; Erbaş, M.; Çetinkaya, C.; Özceylan, E. A GIS-based MCDM approach for the evaluation of bike-share stations. J. Clean. Prod. 2018, 201, 49-60. [CrossRef]

49. Williams, L.; Flowers, P.; McLeod, J.; Young, D.; Rollins, L. Social patterning and stability of COVID-19 vaccination acceptance in Scotland: Will those most at risk accept a vaccine? medRxiv 2020. [CrossRef]

50. Bhaduri, E.; Manoj, B.S.; Wadud, Z.; Goswami, A.K.; Choudhury, C.F. Modelling the effects of COVID-19 on travel mode choice behaviour in India. Transp. Res. Interdiscip. Perspect. 2020, 8, 100273. [CrossRef]

51. Irawan, M.Z.; Belgiawan, P.F.; Joewono, T.B.; Bastarianto, F.F.; Rizki, M.; Ilahi, A. Exploring activity-travel behavior changes during the beginning of COVID-19 pandemic in Indonesia. Transportation 2021. [CrossRef]

52. Astroza, S.; Tirachini, A.; Hurtubia, R.; Carrasco, J.A.; Guevara, A.; Munizaga, M.; Figueroa, M.; Torres, V. Mobility Changes, Teleworking, and Remote Communication during the COVID-19 Pandemic in Chile. Findings 2020, 1, 1-8. [CrossRef]

53. Belzunegui-Eraso, A.; Erro-Garcés, A. Teleworking in the Context of the COVID-19 Crisis. Sustainability 2020, 12, 3662. [CrossRef]

54. Hahn, J. Has Turkey Lost Control of the Coronavirus Pandemic? Available online: https://p.dw.com/p/3mlvD (accessed on 10 February 2021).

55. Kitano, T.; Aoki, H. A model for the incremental burden of invasive Haemophilus influenzae type b due to a decline of childhood vaccination during the COVID-19 outbreak: A dynamic transmission model in Japan. Vaccine 2021, 39, 343-349. [CrossRef] [PubMed]

56. Turkish Statistical Institute Number of Vehicles 2019. Available online: http:/ / www.tuik.gov.tr/PreIstatistikTablo.do?istab_id=36 2 (accessed on 12 February 2021).

57. Republic of the Turkey Ministry COVID-19 Information Page. Available online: https:/ / covid19.saglik.gov.tr/?_Dil=2 (accessed on 10 February 2021).

58. Turkish Statistical Institute (TSI) Population by Province, Single Age and Sex. Available online: https:/ / data.tuik.gov.tr/Bulten/ DownloadIstatistikselTablo?p=8nHwYVFJKFLIkqNS6KXjzqUmg0kXoZyHDjG5Z2WaRW/jFhEZf4GgiLHIt6jidK9C (accessed on 16 January 2021).

59. Reuters COVID-19 Tracker: Turkey. Available online: https://graphics.reuters.com/world-coronavirus-tracker-and-maps/ countries-and-territories/turkey/. (accessed on 11 February 2021).

60. Turkish Statistical Institute (TSI) Health Statistics. Available online: http:/ / www.turkstat.gov.tr/PreIstatistikTablo.do?istab_id= 2926 (accessed on 21 April 2020).

61. Turkish Statistical Institute (TSI) Population and Demography. Available online: http:/ / www.turkstat.gov.tr/PreTablo.do?alt_ id=1047 (accessed on 21 April 2020).

62. Republic of Turkey Ministry of Health COVID-19. Available online: https:/ / covid19.saglik.gov.tr/ (accessed on 21 April 2020).

63. Saaty, T.L. A scaling method for priorities in hierarchical structures. J. Math. Psychol. 1977, 15, 234-281. [CrossRef]

64. Saaty, T.L.; Ozdemir, M.S. Why the magic number seven plus or minus two. Math. Comput. Model. 2003, 38, 233-244. [CrossRef]

65. Castro-Santos, L.; Lamas-Galdo, M.I.; Filgueira-Vizoso, A. Managing the oceans: Site selection of a floating offshore wind farm based on GIS spatial analysis. Mar. Policy 2020, 113, 103803. [CrossRef]

66. Winter, S. Bridging vector and raster representation in GIS. In Proceedings of the 6th ACM International Symposium on Advances in Geographic Information Systems, Washington, DC, USA, 2-7 November 1998; pp. 57-62.

67. Chan, T.O.; Williamson, I.P. The different identities of GIS and GIS diffusion. Int. J. Geogr. Inf. Sci. 1999, 13, 267-281. [CrossRef]

68. Singh, L.K.; Jha, M.K.; Chowdary, V.M. Multi-criteria analysis and GIS modeling for identifying prospective water harvesting and artificial recharge sites for sustainable water supply. J. Clean. Prod. 2017, 142, 1436-1456. [CrossRef]

69. Wang, C.H.; Chen, N. A GIS-based spatial statistical approach to modeling job accessibility by transportation mode: Case study of Columbus, Ohio. J. Transp. Geogr. 2015, 45, 1-11. [CrossRef] 
70. Cronan, K.M. Coronavirus (COVID-19): Getting Tested at a Drive-Thru Testing Site. Available online: https:// kidshealth.org/ en/parents / coronavirus-drive-thru-tests.html (accessed on 22 September 2020).

71. Kumar, P.; Singh, R.K.; Sinha, P. Optimal site selection for a hospital using a fuzzy extended ELECTRE approach. J. Manag. Anal. 2016, 3, 115-135. [CrossRef] 